\title{
ERP and Four Dimensions of Absorptive Capacity: Lessons from a Developing Country
}

\author{
María José Álvarez Gil, Dilan Aksoy, and Borbala Kulcsar \\ Department of Business Administration, Universidad Carlos III de Madrid, \\ C/Madrid, 12628903 Getafe (Madrid) España
}

\begin{abstract}
Enterprise resource planning systems can grant crucial strategic, operational and information-based benefits to adopting firms when implemented successfully. However, a failed implementation can often result in financial losses rather than profits. Until now, the research on the failures and successes were focused on implementations in large manufacturing and service organizations firms located in western countries, particularly in USA. Nevertheless, IT has gained intense diffusion to developing countries through declining hardware costs and increasing benefits that merits attention as much as developed countries. The aim of this study is to examine the implications of knowledge transfer in a developing country, Turkey, as a paradigm in the knowledge society with a focus on the implementation activities that foster successful installations. We suggest that absorptive capacity is an important characteristic of a firm that explains the success level of such a knowledge transfer.
\end{abstract}

Keywords: Knowledge Transfer, Absorptive Capacity, ERP.

\section{Introduction}

In the last few decades, global competition has forced business organizations increase in intensity and complexity. The competing companies seek for crucial capabilities such as fast product development, customized manufacturing and quicker distribution in order to satisfy customer needs and desires.

Information systems, which are the means by which organizations and people, utilizing information technologies, gather, process, store, use and distribute information in business processes, are utilized by most firms to succeed in challenges such as obtaining and sustaining such capabilities.

Organizations provide capability to perform precise, punctual, and efficient operations that lead to effective management and competitive advantage by the contribution of information systems. Those organizations that make use of information systems to enhance how they do business in both domestic and global markets are more likely to obtain significant advantages against their competitors. However, the transfer of such technologies between national cultures might present additional problems of learning and adaptation. From a view point of a developing country, SWOT analysis could be useful as a way to evaluate the advantages and disadvantages of IT applications. 
Strengths: Turkey, as a developing country, has certain advantages for creating a robust IT sector and transforming its economy into an information-based economy. The following advantages, some of which are common to other developing countries, can be listed. (1) Turkey has some advantages as a latecomer to the IT scene. No heavy investments have been made in preliminary technologies. IT departments in the country enjoy the advantage of developing more reliable software in a shorter time on more reliable hardware platforms implementing the new technologies transferred. (2) The hardware costs have decreased steeply during the last few decades. Almost all major international computer vendors operate in the country and therefore the computer market is highly competitive and advantageous for the buyer. (3) In the 1980s Turkey invested heavily in its communications infrastructure which makes it possible to build a potential information-based economy where dissemination of information is of prime importance. (4) Turkey has a large young population with the potential of becoming the key resource of a robust IT sector.

Weaknesses: One major issue that the developing countries face with is the operational needs (e.g. developing reliable software). Cultural differences from Western societies also infer difficulties in transferring knowledge to a developing country. The dominant western mentality in this area forces the developing countries to design and produce software reflecting this dominant western mentality. Therefore, the developing countries have to either adopt this mentality or to create their own alternatives in IT applications. Another important problem of the developing countries is the insufficient qualitative and quantitative formation given to the personnel. This issue is gaining importance since the sophistication of IT is increasing sharply.

Opportunities: Turkey is an attractive location which has an important positioning for foreign companies to enter the emerging central Asia through engaging in joint ventures with Turkish partners. Most of the organizations in Turkey which have implemented ERP are the local subsidiaries of multinationals. This is not surprising since they tend to follow their parent companies' global IT strategies which commonly incorporate ERP. They train their personnel appropriately about the importance of IT and introduce them about the advanced IT applications in the other subsidiaries and headquarters. The required support is provided from the sister organizations or headquarters, they are able to attract and retain high-qualified personnel due to their financial strength, and generally they have the managerial and technical infrastructure needed for the ERP.

Threats: A survey conducted in Norway by Karlsen and Gottschalk confirms that IT project success is significantly related to knowledge transfer [6], [13]. If sufficient training is not provided, the project staff learns on the job, and project duration increases. Unfortunately, numerous studies show that training time is often underestimated and training budgets are often set at very low levels [8], [28]. Robey et. al. conclude that firms that managed to overcome knowledge barriers and successfully assimilate new processes invested approximately 15-20 percent of their project budgets in formal team training. However, the companies that were less successful spent a maximum of 10 percent of their Project budgets on training [24].

We propose that IT applications and implementations, such as ERP, can be seen as knowledge transfer integrated with practical experience. Consequently, absorptive capacity framework could enhance the development of knowledge society by explaining 
the success and failure of this knowledge transfer performed through ERP implementations. Depending upon prior studies and related theoretical framework we suggest that due to cultural and organizational constraints in transferring technology to a developing country that is lack of the western mentality, extensive training and absorptive capacity have crucial effects on the success of IT projects.

The rest of the paper proceeds as follows. First of all, we focus on those aspects of absorptive capacity that critically determine the success of an ERP implementation that brings high profits. Secondly, a brief description on ERP is given and its benefits for companies are stated. Afterwards, three companies in Turkey that have implemented ERP software successfully were examined to understand the key points leading to profitable installations. Finally, we integrate the relevant theoretical background with the cases and conclude with the contributions that absorptive capacity brings to successful IT projects.

\section{Literature Review}

Background on absorptive capacity: Levinthal and Cohen define a firm's absorptive capacity as the ability of a firm to recognize the value of new external information, assimilate it, and apply it to commercial ends. Absorptive capacity varies across firms since it is generated in a variety of ways [5]. For instance, Levinthal and Cohen suggest that prior related knowledge effects the ability to evaluate and utilize outside knowledge to a great extend. Moreover, they argue that absorptive capacity might be built by sending firms' personnel for advanced technical training.

In a recent article, Zahra and George elaborate the absorptive capacity model [31]. According to Zahra and George, absorptive capacity has four dimensions - acquisition, assimilation, transformation, and exploitation - where the first two dimensions form potential absorptive capacity; the latter two dimensions form realized absorptive capacity. They argue that more attention should be given to studying the realized absorptive capacity which emphasizes the firm's capacity to leverage the knowledge that has been previously absorbed. As put forward by Zahra and George, firms can acquire and assimilate knowledge but might not have the capability to transform and exploit the knowledge for profit generation [31].

We follow the idea of Zahra and George and emphasize the four dimensions of absorptive capacity in ERP projects. Acquiring and assimilating capabilities, in the case of an ERP project, might be analogous to buying it from the vendor and training the personnel with the aim of assimilating this new knowledge. The transformation capability could be parallel to the customization or development processes of the ERP package taking into account firms' specific needs. On the other hand, exploitation capability might increase due to management support and employee belief in the project. Based upon this four-dimensional absorptive capacity framework, we suggest that success of an ERP project varies to a great extend with the transformation and exploitation capability of a firm which is also called the realized absorptive capacity.

An overview of ERP system: Enterprise Resource Planning (ERP) system is defined as "A software solution that carries out all the functions of an enterprise to succeed in organizational goals as a collection of integrated subsystems." ERP provides organizations with efficient and consistent data gathering. It also establishes a common data infrastructure for the use of various functions and activities. 
Companies implementing the standard ERP Package need the adaptation of the ERP package to suit their requirements. In order to achieve this, technical aspects of the ERP package as much as the functional aspects of the business have to be well understood. The flexibility of ERP Package allows project team to meet the company process requirements with the capabilities of the standard package in the implementation process. ERP vendors don't design the standard packages with the expectations of fulfilling the companies' own business processes. Henceforth, company processes are generally changed to obey package functionalities.

One important issue in ERP implementation is determining the extent to which organizational processes need to be changed to fit into the enterprise system framework and the extent to which the enterprise system must be customized to address existing routines in the organization.

Various aspects of a firm's operations and performance are affected by ERP implementation. Therefore, commitment of top management and employees to the project is highly desirable. During the last decade, numerous failed ERP implementation cases indicated that ERP implementation transforms a company's organizational structure, business process, and employee involvement extensively [1], [29]. The literature on ERP implementation has suggested various critical practices during the implementation of ERP system. For instance, experiencing the inconsistency between the ERP package and firms' current production process and organizational structure would be inevitable. Whether to revise the ERP package or to adapt their current business process to meet the requirement of IT package implementation would be an important decision to be made by the managers. Employees' behavioral dynamics in ERP implementation should not be underestimated near to that of managers and staff members. Top management commitment, employee involvement, and functional area support are suggested to be the foundations to successful ERP implementations by prior studies [3].

\section{Case Studies in the Implementation of ERP Systems}

Many researchers have been suggesting the case study research methodology for developing conceptual and descriptive understanding of complex phenomena [9], [19], [30]. ERP implementation process, which extends across the whole organization, might be considered as a complex issue taking into consideration the expensive and extensive activities undertaken including planning, justifying, installing and commissioning of the installed system [22].

There are many benefits of the case study method including the ability to observe causality and harvest evidence and logic to build, develop or support theory [18]. When compared to survey research methods, it enables researchers for more valuable follow-up questions to be asked and answered and can result in more extensive findings and insights that are valid, generalizable and rigorous [20].

In this study, we use a longitudinal case study methodology analyzing three diverse companies with the aim of describing the steps in the process and to investigate the complex relationships between these steps. The companies included in this study are manufacturing companies competing in different industries. 


\subsection{Company A}

Since 1999, Company A's single business focus was on consulting services that it rendered relating to drilling. In 2002, due to changes taking place in the business, they decided to diversify and started to export natural stone. Currently, Company A exports natural stone to U.S., Italy, France, Netherlands, U.K. and Canada. They maintain their own warehouses in the U.S. and Italy. They work with about 80 producers in Turkey; they do not have production operations of their own and engage in trading only.

In 2005, the company came to the conclusion that the order processing they were performing using Microsoft Excel and accounting software was proving to be too problematic, and they decided to search for a solution that would fit their organization. So, they decided to purchase a software program. The mistake they made at the time was not to assign a dedicated person to be the responsible contact point for this software in the organization.

For about a year, they tried in vain to get the program to conform to the way the company do business. For everyone, it was much easier to continue to use Excel than to transition to the use of the new software. Then in January 2007, an industrial engineer was hired to help in the planning activities of the company. This new person was assigned to the task of running that project, which, looking at where the company is now, has proven to be a very accurate decision.

The manager of the company states that the flexibility of the ERP system, delivered with accompanying source code, they have been using is of great importance. He also points out that their business processes are very distinct, and accordingly, a number of customizations have been developed that are unique to the company. The packaging process required special attention. Development was performed that made it possible to show the corresponding sales activity for each purchase order. This provided them with the ability for traceability within the system. One of the major benefits for the company has been the dramatic drop in error rates.

\subsection{Company B}

The company has completed 42 years in the automotive supplier industry, together with 2 manufacturing factories, 10 district retailers, 199 authorized service points and 700 client network, has been serving all over Turkey. The company has become a known and sought brand in more than 30 countries with its foreign dealers and customers, having been the provider for the main automotive manufacturers in Turkey and abroad, increasing the success and development in the international market as much as in Turkey.

$52 \%$ of the production is exported. Expanding accelerates increasingly. Being the leader in the sector, the company has to increase the efficiency continuously and has to pursuit and plan the production closely. The need of continuous development, made ERP inevitable for the company. The company was ready in all sides before starting the ERP project. The necessary personnel had been provided. The management believed in the project and made the employees believe in it.

The managers emphasize that there are several other package programs in the market that limit the firms in several ways. Henceforth, using such commercial packages might turn into a disadvantage for firms in the process of employing ERP. They also suggest that users should give up with those packages that include narrow templates and habits in order to achieve successful ERP implementations. 


\subsection{Company $\mathrm{C}$}

The company was built as a partnership between a Turkish firm and a French firm in 1994. Essentially, it emerged as a continuation of the Turkish firm that was found in 1984 and was producing plastic and metal components for the automotive supply industry. In 1994 through the direction of the need of the sector, the projects in Europe started to be transferred to Turkey synchronously. Accordingly, with the need of low project investment costs, foreign partnerships gained importance among the main automotive manufacturers. For instance, the first Renault Megane project run in Turkey is such a project which came out in France and was in serial production in Turkey 7-8 month afterwards.

The company started to work with a Turkish ERP vendor in 2005. The company states that an important reason to work with them was that their Turkish partnership was working with them and a serious synergy was generated consequently. They transferred the implementation experience from the Turkish partner to the company. Both of the two companies work in the same business line, producing metal and plastic for the automotive supply industry. Since the business processes were similar, the company was able to integrate the system more easily by providing them with sufficient raining. Another important characteristic of the software preferred was its open-source code that made the company able to develop it according to their needs.

The company believes that the greatest lack would be the support of the company management to the ERP project. If the company management doesn't support or supports the projects with question marks, then it is inevitable for the employees to get de-motivated and difficulties arise in the project.

\section{Conclusions}

ERP is getting to become widely used day by day for companies in developing countries and they see that if they implement ERP software successfully, everything will be in order. However, low implementation success rates force the companies develop alternatives of implementation. While some companies develop their own ERP systems, some of them prefer standard ERP packages and some of them prefer to have a hybrid system with an open-source code so that they can develop the system according to their specific needs.

In line with our proposition, firms that achieve successful ERP projects in this study have concentrated to a great deal on planning, justification, training, installation and development practices that are the key issues in successful knowledge transfer through an increased absorptive capacity.

Future studies can focus on determining whether the theory aforementioned can be used as a framework for the success of other integrated technology adoptions, or if unlike technologies have some specific success characteristics.

\section{References}

1. Akkermans, H., Bogerd, P., Yucesan, E., van Wassenhove, L.N.: The impact of ERP on a supply chain management: Exploratory findings from a European Delphi study. European Journal of Operational Research 146, 284-301 (2003) 
2. Barney, J.B.: Firm Resources and Sustained Competitive Advantage. Journal of Management 17, 99-120 (1991)

3. Berinato, S.: A day in the life of Celanese's big ERP Rollup. CIO Magazine, 54-63 (January 15, 2003)

4. Birdoğan, B., Dereli, T., Baykasoğlu, A.: An investigation on the readiness of Turkish companies for enterprise resource management. Journal of Manufacturing Technology Management 15, 50-56 (2004)

5. Cohen, W.M., Levinthal, D.A.: Absorptive Capacity: A new Perspective on Learning and Innovation. Administrative Science Quarterly 35(1), 128-152 (1990)

6. Dixon, N.M.: Common Knowledge. Harvard Business School Press, Boston (2000)

7. Escribano, A., Fosfuri, A., Tribo, J.A.: Managing External Knowledge Flows: The Moderating Role of Absorptive Capacity. Research Policy 38, 96-105 (2009)

8. Fletcher, P.T., Bretschneider, S.I., Marchand, D.A.: Managing information technology: Transforming country governments in the 1990s. Syracuse University School of Information Studies, Syracuse, NY (1992)

9. Flynn, B.B., Sakakibara, S., Schroeder, R.G., Bates, K.A.: Empirical research methods in operations management. Journal of Operations Management 9(2), 250-284 (1990)

10. Hitt, M.A., Dacin, M.T., Levitas, E., Arregle, J., Borza, A.: Partner Selection in Emerging and Developed Market Contexts: Resource-based and Organizational Learning Perspectives. Academy of Management Journal 43(3), 449-467 (2000)

11. Jacobs, F.R., Bendoly, E.: Enterprise Resource Planning: Developments and Directions for Operations Management Research. European Journal of Operational Research 146, 233$240(2003)$

12. Jansen, J.J., Van Den Bosch, F.A.J., Volberda, H.W.: Management Potential and Realized Absorptive Capacity: How do Organizational Antecedents Matters? Academy of Management Journal 48(6), 999-1015 (2005)

13. Karlsen, J.T., Gottschalk, P.: An empirical evaluation of knowledge transfer mechanisms for IT projects. Journal of Computer Information Systems 44(1), 112-119 (2003)

14. Kirlidog, M.: Information Technology Transfer to a Developing Country: Executive Information Systems in Turkey. OCLC Systems \& Services 13, 102-123 (1996)

15. Lane, P.J., Lubatkin, M.: Relative Absorptive Capacity and Interorganizational Learning. Strategic Management Journal 19(5), 461-477 (1998)

16. Lane, P.J., Salk, J.E., Lyles, M.A.: Absorptive Capacity, Learning, and Performance in International Joint Ventures. Strategic Management Journal 22(12), 1139-1161 (2001)

17. Li, L., Marcowski, C., Xu, L., Markowski, E.: TQM-A predecessor of ERP implementation. International Journal of Production Economics 115, 569-580 (2008)

18. Maffei, M.J., Meredith, J.R.: Infrastructure and flexible manufacturing technology: theory development. Journal of Operations Management 13(4), 273-298 (1995)

19. McCutcheon, D.M., Meredith, J.R.: Conducting case study research in operations management. Journal of Operations Management 11(3), 239-256 (1993)

20. Meredith, J.R.: Building operations management theory through case and field research. Journal of Operations Management 16, 441-454 (1998)

21. Minbaeva, D., Pedersen, T., Bjorkman, I., Fey, C.F., Park, H.J.: MNC Knowledge Transfer, Subsidiary Absorptive Capacity, and HRM. Journal of International Business Studies 34(6), 586-599 (2003)

22. Muscatello, J.R., Small, M.H., Chen, I.J.: Implementing enterprise resource planning (ERP) systems in small and midsize manufacturing firms. International Journal of Operations \& Production Management 23, 850-871 (2003) 
23. Plaza, M., Rohlf, K.: Learning and Performance in ERP Implementation Projects: A learning-curve model for analyzing and managing consulting costs. Int. J. Production Economics $115,72-85$ (2008)

24. Robey, D., Boudreau, M.C., Ross, J.: Learning to implement enterprise systems: An exploratory study of the dialectic of change. In: CISR Working Papers. MIT, Cambridge (2000)

25. Sarkis, J., Gunasekaran, A.: Enterprise resource planning: Modeling and Analysis. European Journal of Operational Research 146, 229-232 (2003)

26. Selekler-Gökşen, N., Uysal-Tezölmez, H.: Control and Performance in International Joint ventures in Turkey. European Management Journal 25, 384-394 (2007)

27. Vandaie, R.: The role of organizational knowledge management in successful ERP implementation projects. Knowledge-Based Systems 21, 920-926 (2008)

28. Wu, L., Rocheleau, B.: Formal versus informal end user training in public and private sector organizations. Public Performance and Management Review 24(4), 312-321 (2001)

29. Xu, L.: Editorial. Enterprise Information Systems 1(1), 1-2 (2007)

30. Yin, R.K.: Case Study Research: Design and Methods, 2nd edn. Sage Publications, Newbury Park (1994)

31. Zahra, S.A., George, G.: Absorptive Capacity: A review, Reconceptualization, and Extension. Academy of Management Journal 27(2), 185-203 (2002) 